DOI https://doi.org/10.18551/rjoas.2020-09.11

\title{
THE INFLUENCE OF WORK DISCIPLINE AND ORGANIZATIONAL COMMUNICATION ON EMPLOYEE PERFORMANCE WITH WORK MOTIVATION AS INTERVENING VARIABLE AT YOGYAKARTA YOUTH AND SPORTS CENTER
}

\author{
Adytya Mohammad Rezza* \\ Master's Program of Management, Postgraduate Program, Faculty of Economics and \\ Business, Universitas Pembangunan Nasional Veteran Yogyakarta, Indonesia \\ Winarno, Wisnalmawati, Lecturers \\ Faculty of Economics and Business, Universitas Pembangunan Nasional Veteran \\ Yogyakarta, Indonesia \\ *E-mail: winarno feupn@yahoo.com
}

\begin{abstract}
This study aims to analyze the effect of work discipline and organizational communication on employee performance with motivation as an intervening variable. Data collection was carried out in July 2020. Respondents in this study were Civil Servants (PNS) who were at the Yogyakarta Youth and Sports Center. Work discipline is one of the factors that determine employee motivation and performance. Given that work discipline is an attitude that must be possessed by every employee that causes behavior that leads to certain goals. Supported by good organizational communication, the results will be more competent. The results obtained: (1) Work discipline has a positive and significant effect on employee performance. (2) Work discipline has a positive and significant effect on employee performance with motivation as an intervening variable. (3) Organizational communication has a positive and significant effect on employee performance. (4) Organizational communication has a positive and significant effect on employee performance with motivation as an intervening variable. The implications for the findings in this study are work discipline, organizational communication, motivation as an intervention has an influence on employee performance. The end result is that the leadership continues to provide encouragement so that employees work more actively, and in making organizational policies are always communicated with subordinates, providing facilities and opportunities for subordinates to convey ideas or ideas that are useful to the organization.
\end{abstract}

\section{KEY WORDS}

Work discipline, organizational communication, motivation, performance.

Human resources management (Human Resource Management) is an activity that includes management, development, SSR assessment, provision of remuneration to people or individuals within the organization or institution members. Human resource management is also about ways of designing the $s$ tem planning, employees, career management, job evaluation, employee compensation, and labor relations. Human resource management involves all management practices that can affect directly on the organization. The role of human resources today is a determinant for the success of an activity carried out in an organization, whether private or corporate, state-owned or government agencies (Arikunto, 1996 in Supriyanto, et al, 2013).

In government agencies, apart from having the advantage of one individual, they are also able to work together with teams or organize. Efforts to improve employee performance cannot be separated from employee discipline (Maharani, 2010). From the research results of Izaz Dany Afianto (2017), it is known that work discipline has a significant positive effect on employee performance. If employees are not disciplined, it will interfere with work results and employee activities on a regular basis, the work should be completed today, there are 
still many jobs pending and cannot be completed on time. According to research by Siti Noer Istiqomah (2015), it is clear that discipline has a significant effect on employee performance.

Organizational communication can be defined as the performance and interpretation of messages among communication units that are part of a particular organization. "An organization consists of communication units in hierarchical relationships between one another and functions in an environment" (Pace and Faules, 2013: 31).

The most serious challenge faced by management today is to achieve the goals and survival of the company or an organization, which is influenced by the quality of the performance of human resources in it. Performance is defined as "the results of the work itself (Outcomes of work)". For government organizations, personnel management always strives to become an effective and efficient organization in providing services to the community quickly, precisely and professionally.

The job appraisal system for Civil Servants (PNS) has been regulated by the government and stipulated in government regulations. This work appraisal system is contained in PP 46 of 2011. Improving performance in an agency is a difficult challenge. Because employee performance is measured by how much the employee contributes to the organization.

The performance conditions of employees at the Yogyakarta Youth and Sports Center show low performance such as delays in coming to work, not going to the office without a trip to not being in the office when the working hours are not over. This is presumably due to a lack of discipline within an organization. Even though on the other hand with a good work discipline it will provide motivation in improving employee performance. Hasibuan (2015) explains that good discipline reflects the amount of responsibility a person has for the tasks assigned to him.

The research objectives in this study include:

- Knowing and analyzing the effect of work discipline on employee performance at the Yogyakarta Youth and Sports Center;

- Knowing and analyzing the influence of organizational communication on employee performance at the Yogyakarta Youth and Sports Center;

- Knowing and analyzing the influence of work motivation as an intervening on employee performance at the Yogyakarta Sports and Youth Center;

- Knowing and analyzing the effect of work discipline on employee performance with work motivation as an intervening, at the Yogyakarta Youth and Sports Center;

- Knowing and analyzing the influence of organizational communication on employee performance with work motivation as an intervening, at the Yogyakarta Youth and Sports Center.

\section{LITERATURE REVIEW}

According to Hasibuan (2015), discipline is the key to the success of a company in achieving its goals. Discipline is an important function in an organization because the better the employee's discipline, the higher work performance they can achieve. Conversely, without discipline, it is difficult for corporate organizations to achieve optimal results. According to Rivai (2006) discipline is a tool used by managers to communicate with employees so that they are willing to change a behavior as well as an effort to increase one's awareness and willingness to comply with all company regulations and applicable social norms.

Communication is a basic human activity. Communication helps organizational members achieve individual and organizational goals, respond to and implement organizational changes and play a role in almost all relevant organizational actions. Good communication can be the right means of improving employee performance. Through communication, employees can ask superiors for instructions regarding work implementation.

Robbins, and Judge (2013: 202) argue that motivation is the desire to do as a willingness to spend a high level of effort for organizational goals, which is conditioned by the 
ability of that effort to meet an individual need as well as motivation as a process that determines intensity, direction, and individual persistence in achieving goals. Whereas Mangkunegara (2011: 93) motivation comes from the word motive which is an encouragement of the needs of employees that need to be met so that these employees can adapt to their environment.

Performance, according to Wake Wilson (2012: 231), is the result of work performance achieved by terms and requirements of the job (Job Requirements). Employee performance for agencies and companies is very important as a measure of success in carrying out the goals of the organization or business, because employee performance is the final result of the work achievement of the employee or employee that shows their success in carrying out their duties. In government agencies, this is stated in the Government Regulation of the Republic of Indonesia Number 46 of 2011 which describes the work performance assessment of Civil Servants.

\section{METHODS OF RESEARCH}

This research was carried out in this study carried out at the Youth and Sports Center Yogyakarta a. Independent variables: work discipline and organizational communication, the dependent variable is employee performance and the mediating variable is work motivation.

Employee performance is the final result of the employee's or employee's work achievement that shows their success in carrying out their duties. In government agencies, this is stated in the Government Regulation of the Republic of Indonesia Number 46 of 2011 which describes the work performance assessment of Civil Servants. Employee performance appraisal is determined through elements which include the following;

- Employee Work Goals (SKP) / Academic Achievement Value (60\%);

- Work Behavior (40\%).

Work motivation is a skill, in directing employees and organizations to work successfully so that the wishes of employees and organizational goals at the Youth and Sports Hall Office can be achieved. In this study, researchers used indicators according to David Mc's Achievement Motivation theory. This theory focuses on three needs which is also used as an indicator of work motivation: The indicators used are: a) Need for Achievement; b) Need for Affiliates; c) The Need for Power.

Pace and Faules (2013: 31) says that the organizational communication is defined as the performance and interpretation of messages between communication units that are part of a particular organization, Indicators: 1. Faith, 2 Making decisions together, 3. Honesty,, 4. Openness in downward communication, 5. Listening in upward communication, 6. Attention to high-performance goals.

Work discipline is a tool used by managers to communicate with employees so that they are willing to change behavior as well as efforts to increase one's awareness and willingness to comply with all applicable company rules and social norms.

According to Mangkunegara and Octorent (2015) work discipline can be measured by the following indicators: 1) Timeliness of coming to the workplace; 2) Punctuality of time to go home; 3) Compliance with applicable regulations. 4) Responsibility in carrying out duties. 5) Carry out work tasks to completion every day.

Employee Centers for Youth and Sports Yogyakarta dominated by employees of men men as many as 30 employees or 71,4 percent of the total respondents, while for female employees amounted to 12 people or 28, 6 percent of the total respondents. The Yogyakarta Youth and Sports Center is in charge of youth and sports organizations in both formal and non-formal education settings, and the job descriptions needed to find employees are also tailored to these fields.

In this study, describes the description of the results of respondents' answers to research variables which include work discipline and organizational communication on performance with motivation as the mediating variable. This assessment is based on the average score for each variable based on the minimum score and the maximum score. 
Table 1 - Assessment of Yogyakarta Youth and Sports Hall Employees on Work Discipline Variable

\begin{tabular}{|l|l|l|l|}
\hline No. & Work Discipline Statement Items & Average & Category \\
\hline 1 & Work optimally & 4.00 & High \\
\hline 2 & It is never late and always present on time & 2.76 & Enough \\
\hline 3 & Willing to work overtime & 3.60 & High \\
\hline 4 & If the working time is over always hurry to leave the workplace & 4.40 & Very High \\
\hline 5 & Each work must be no result & 4.10 & High \\
\hline 6 & Work should be focused and consistent & 4.24 & Very High \\
\hline 7 & If you make a mistake, your boss often gives a warning & 3.45 & High \\
\hline 8 & Not come to work without a clear explanation & 3.88 & High \\
\hline 9 & Work professionally & 4.21 & Very High \\
\hline 10 & Correct the error if there is an error & 3.93 & High \\
\hline The average total work discipline & 3.86 & High \\
\hline No. & Organizational Communication Statement Items & Average & Category \\
\hline 1 & The boss tells how the work is going. & 4.07 & Well \\
\hline 2 & Bosses provide information about policies that will be carried out & 4.14 & Well \\
\hline 3 & Ideas are conveyed directly to superiors & 4.02 & Well \\
\hline 4 & Work communicated to superiors & 3.86 & Well \\
\hline 5 & Trust in colleagues in doing work & 3.95 & Well \\
\hline 6 & Different positions are not a barrier to obtaining information while working & 3.98 & Well \\
\hline 7 & Differences in division are not a barrier to expressing opinions & 4.02 & Well \\
\hline 8 & Can work together and coordinate with each other to get work done & 3.93 & Well \\
\hline 9 & $\begin{array}{l}\text { Fellow employees will remind each other of work actions that are not in } \\
\text { accordance with work regulations }\end{array}$ & 4.02 & Well \\
\hline 10 & $\begin{array}{l}\text { If you experience problems at work do not hesitate to convey this to } \\
\text { colleagues and superiors }\end{array}$ & 4.07 & Well \\
\hline 11 & If employees work together, it will be very helpful in achieving work targets & 4.19 & Well \\
\hline 12 & All employees in the office have high morale & 3.79 & Well \\
\hline Average total organizational communications & 3.98 & Well \\
\hline
\end{tabular}

It is known that most respondents gave an assessment of work discipline variables in the high category (Mean 3, 86). This shows that employees have high work discipline. Labor discipline highest in the indicator if a work has been completed are always rushing to leave the workplace with an average of 4, 40, and the lowest score is an indicator that never late and always come on time with a score of 2, 76 (enough).

42 respondents were sampled, known to most respondents provide an assessment variable organizational communication in the category of good (Mean 3, 98). This shows that employees have good organizational communication with colleagues and superiors. Organizational communication is highest in the indicator a sovereign, when among employees working together it will greatly assist in the achievement of employment targets by an average of 4,19 , and the lowest score is the indicator's existing employees at the office have high morale with a score of 3,79 (good).

Table 2 - Assessment of Yogyakarta Youth and Sports Center Employees on Work Motivation Variables

\begin{tabular}{|l|l|l|l|}
\hline No. & Motivation Statement Items & Average & Category \\
\hline 1 & You always try to be the best every time you work & 4.36 & Very High \\
\hline 2 & If given the trust of the boss, always try to give the best results and work optimally & 4.21 & Very High \\
\hline 3 & Openness between employees at work increases enthusiasm for work & 3.86 & High \\
\hline 4 & Equal rights among employees motivate them to work to get good results & 3.55 & High \\
\hline 5 & The hope of a guarantee in old age makes him eager to work & 3.60 & High \\
\hline 6 & Passionate about working in order to get a certain position at work & 3.31 & Enough \\
\hline \multicolumn{2}{|l|}{ Average - average motivation } & 3.81 & High \\
\hline
\end{tabular}

The majority of respondents gave an assessment of work motivation variables in the high category (Mean 3, 81). This shows that employees have high work motivation, namely the drive to fulfill the needs for achievement, affiliation, and power. Work motivation is highest in the indicator will always strive to be the best of each work with an average of 4 , 
36 , and the lowest score is an indicator excited to work in order to obtain a certain position on the job with a score of 3,31 (enough).

Table 3 - Assessment of Yogyakarta Youth and Sports Center Employees on Employee Performance Variables

\begin{tabular}{|l|l|l|l|}
\hline No. & Performance Statement Items & Average & Category \\
\hline 1 & What is done is in accordance with the established performance standards & 4.00 & Well \\
\hline 2 & Complete work according to ability & 3.93 & Well \\
\hline 3 & Work is always satisfying & 4.00 & Well \\
\hline 4 & Every employee must have the ability to complete the job well & 3.79 & Well \\
\hline 5 & Work will be neglected if you don't come to work & 3.88 & Well \\
\hline 6 & Notify superiors when absent from work & 3.88 & Well \\
\hline 7 & If asked for help by colleagues, be willing to help & 3.93 & Well \\
\hline 8 & If you have difficulty working, colleagues will definitely help & 3.81 & Well \\
\hline \multicolumn{2}{|l|}{ Average performance } & 3.90 & Well \\
\hline
\end{tabular}

It is known that the majority of respondents gave an assessment of performance variables in the agreed category (Mean 3, 90). This shows that employees have high performance. Performance was highest on indicators of a pa who do are in accordance with the performance standards that have been defined by an average of 4,00 , and the lowest score is an indicator $s$ ach employee must have the ability to finish the job properly with a score of 3,79 .

\section{RESULTS AND DISCUSSION}

Before carrying out any processing or processing to analyze data, there are several criteria for using data analysis techniques using SmartPLS.

Table 4 - The value of loading factors for all indicators of exogenous and endogenous variables

\begin{tabular}{|c|c|c|c|c|c|}
\hline No. & Variable & Indicator & & Original Sample (O) & Information \\
\hline \multirow{10}{*}{1} & \multirow{10}{*}{ WORK DISCIPLINE } & \multirow[b]{2}{*}{ Based on Punctuality to Work } & $\mathrm{X} 1.1 .1$ & 0.736 & Valid \\
\hline & & & $\mathrm{X} 1.1 .2$ & 0.785 & Valid \\
\hline & & \multirow{2}{*}{ Home Time Accuracy } & $\mathrm{X} 1.2 .1$ & 0820 & Valid \\
\hline & & & $\mathrm{X} 1.2 .2$ & 0.770 & Valid \\
\hline & & \multirow{2}{*}{ Carrying out work assignments to completion every day } & $\mathrm{X} 1.3 .1$ & 0.784 & Valid \\
\hline & & & $\mathrm{X} 1.3 .2$ & 0.732 & Valid \\
\hline & & \multirow{2}{*}{ Compliance with Applicable Regulations } & $\mathrm{X} 1.4 .1$ & 0.628 & Valid \\
\hline & & & $\mathrm{X} 1.4 .2$ & 0.752 & Valid \\
\hline & & \multirow{2}{*}{ Responsible } & $\mathrm{X} 1.5 .1$ & 0.768 & Valid \\
\hline & & & $\mathrm{X} 1.5 .2$ & 0.721 & Valid \\
\hline \multirow{12}{*}{2} & \multirow{12}{*}{ ORGANIZATIONAL COMMUNICATION } & \multirow{2}{*}{ Openness in Downward Communication } & $\mathrm{X} 2.1 .1$ & 0.675 & Valid \\
\hline & & & $\mathrm{X} 2.1 .2$ & 0.571 & Valid \\
\hline & & \multirow{2}{*}{ Listening In Upward Communication } & $\bar{X} 2.2 .1$ & 0.733 & Valid \\
\hline & & & $\mathrm{X} 2.2 .2$ & 0.715 & Valid \\
\hline & & \multirow{2}{*}{ Trust } & $\mathrm{X} 2.3 .1$ & 0.666 & Valid \\
\hline & & & $\mathrm{X} 2.3 .2$ & 0.607 & Valid \\
\hline & & \multirow{2}{*}{ Joint Decision Making } & $\mathrm{X} 2.4 .1$ & 0.727 & Valid \\
\hline & & & $\mathrm{X} 2.4 .2$ & 0.775 & Valid \\
\hline & & \multirow{2}{*}{ Honesty } & $\mathrm{X} 2.5 .1$ & 0827 & Valid \\
\hline & & & $\mathrm{X} 2.5 .2$ & 0.810 & Valid \\
\hline & & \multirow{2}{*}{ Attention to High Performing Goals } & $\mathrm{X} 2.6 .1$ & 0.709 & Valid \\
\hline & & & $\mathrm{X} 2.6 .2$ & 0.762 & Valid \\
\hline \multirow{6}{*}{4} & \multirow{6}{*}{ MOTIVATION } & \multirow{2}{*}{ Need for Achievement } & $\mathrm{Z} 1.1$ & 0.786 & Valid \\
\hline & & & $\mathrm{Z1.2}$ & 0.761 & Valid \\
\hline & & \multirow{2}{*}{ Need for Affiliates } & Z2.1 & 0.810 & Valid \\
\hline & & & $\mathrm{Z} 2.2$ & 0.763 & Valid \\
\hline & & \multirow{2}{*}{ The Need for Power } & Z3.1 & 0.732 & Valid \\
\hline & & & $\mathrm{Z3.2}$ & 0.704 & Valid \\
\hline \multirow{8}{*}{3} & \multirow{8}{*}{ PERFORMANCE } & \multirow{2}{*}{ Quantity of Work } & $\overline{Y 1.1}$ & 0.749 & Valid \\
\hline & & & Y1.2 & 0.698 & Valid \\
\hline & & \multirow{2}{*}{ Quality of Work } & $\overline{Y 2.1}$ & 0.784 & Valid \\
\hline & & & Y2.2 & 0.685 & Valid \\
\hline & & \multirow{2}{*}{ Presence } & Y3.1 & 0800 & Valid \\
\hline & & & Y3.2 & 0.909 & Valid \\
\hline & & \multirow{2}{*}{ Cooperation Ability } & Y4.1 & 0842 & Valid \\
\hline & & & Y4.2 & 0827 & Valid \\
\hline
\end{tabular}

According to Chin (1998) an indicator is stated to have good validity if the loading factor value is $\geq 0.70$, while the value of 0.5 to 0.6 can be maintained for a model that is still in the development stage. This result means that work discipline, organizational 
communication, work motivation, and organizational performance have met the standard value of convergent validity because all factors have a value of more than 0.5 . Thus, it can be concluded that all constructs are valid.

Variable Reliability Test (Composite Reliability). In addition to the validity of the variables, a construct reliability test was carried out as measured by the composite reliability of the indicator block measuring the construct. The construct is declared reliable if the composite reliability value is above 0.70 (Ghozali, 2015).

Table 5 - Variable Reliability Test Results

\begin{tabular}{|c|c|c|c|c|}
\hline $\mathrm{n} / \mathrm{n}$ & Cronbach's Alpha & rho_A & Composite Reliability & Average Variance Extracted (AVE) \\
\hline Work Discipline & 0.914 & 0.917 & 0.928 & 0.564 \\
\hline Employee Performance & 0.912 & 0.918 & 0.929 & 0.624 \\
\hline Organizational Communication & 0.914 & 0.922 & 0.927 & 0.516 \\
\hline Work motivation & 0.855 & 0.865 & 0891 & 0.578 \\
\hline
\end{tabular}

It can be seen that the value of all variables in the reliability test uses the validity test using AVE with a value of more than 0,5 or Composite Reliability, the value is more than 0.7. Therefore, it can be concluded that the tested variables are valid and reliable, so that it can be continued to test the structural model.

Hypothesis testing can be carried out with due regard to the level of significance and the parameters of the path between the latent variables. The hypothesis is proposed to determine the relationship of each hypothesized construct. Decision making is based on the direction of the relationship and the significance of the test model between constructs which is the output of the inner weight with the help of PLS 3.0 software.

From the path analysis test, the relationship between constructs is obtained as follows:

Table 6 - Results of Testing the Relationship between Variables (Hypothesis Test)

\begin{tabular}{|l|c|c|c|c|}
\hline \multicolumn{1}{|c|}{ Variable relationship pattern } & $\begin{array}{c}\text { Original Sample } \\
(\mathrm{O})\end{array}$ & $\begin{array}{c}\text { T Statistics } \\
(\mid \text { O / STDEV })\end{array}$ & P Values & Information \\
\hline Work discipline -> Employee Performance & 0.376 & 5,518 & 0.000 & Significant \\
\hline $\begin{array}{l}\text { Organizational Communication -> Employee } \\
\text { Performance }\end{array}$ & 0.436 & 6,119 & 0.000 & Significant \\
\hline
\end{tabular}

The table above shows the relationship between variables: Between work discipline (X1) and Employee Performance (Y), the estimated coefficient value is 0.376 and $t$ is 5.518 and a probability is $0.000<0.05$, it can be concluded that there is a significant influence between the disciplines Work (X1) with Employee Performance (Y). The positive path coefficient indicates that the better the employee's work discipline, the higher the employee performance and vice versa. Thus, the first hypothesis $(\mathrm{H} 1)$ which says " H1: work discipline has a positive effect on employee performance at the Youth and Sports Center " is proven and accepted.

Effect of Organizational Communication (X2) with Employee Performance (Y), the estimated coefficient value is 0.436 with t count of 6.119 and a probability of 0.000 where the value is less than 0.05 (significance level of $5 \%$ ), it can be concluded that there is a significant influence between Organizational Communication (X2) and Employee Performance (Y). The positive coefficient shows that the better the Organizational Communication, the higher the employee' performance and vice versa. Thus the second hypothesis $(\mathrm{H} 2)$ which says " H2: Organizational communication has a positive effect on employee performance at the Youth and Sports Center " is proven and accepted.

To test the intervening effect (indirect effect) used the Sobel test. The results of the indirect effect test between constructs can be shown in the following table. 
Table 7 - Indirect Influence

\begin{tabular}{|c|c|c|c|c|}
\hline \multirow{2}{*}{ Variable relationship pattern } & \multicolumn{3}{|c|}{ Indirect Effects / Sobel Test } \\
\cline { 2 - 5 } & $\begin{array}{c}\text { Sobel Test } \\
\text { Coefficient }\end{array}$ & Z count & $P$ Values & Information \\
\hline $\begin{array}{c}\text { Work discipline -> Work Motivation -> Employee } \\
\text { Performance }\end{array}$ & 0.091 & 2.1178 & 0.034 & Significant \\
\hline $\begin{array}{c}\text { Organizational Communication -> Work Motivation -> } \\
\text { Employee Performance }\end{array}$ & 0.139 & 2.4962 & 0.012 & Significant \\
\hline
\end{tabular}

Source: Primary data processed, 2020.

The coefficient of the indirect effect of labor discipline (X1) to employee performance $(Y)$ through the Work Motivation $(Z)$ is equal to 0,091 to the significance test values obtained $Z$ count equal to 2,1178 and the probability amounting to 0.034 where the value is less than 0.05 (at a significant level of $5 \%$ ), it can be concluded that there is a significant influence between work discipline (X1) on Employee Performance (Y) through Work Motivation (Z). Thus, work motivation is a variable that intervene the relationship between work discipline and employee performance. These results at the same time support the third hypothesis $(\mathrm{H} 3)$, namely " H3: Work discipline intervening by motivation has a positive effect on employee performance at the Youth and Sports Center".

note that the coefficient of the indirect effect of Communications Organizational $(X 2)$ of the Employee Performance $(Y)$ through the Work Motivation $(Z)$ is equal to 0,139 to the significance test obtained by value t count equal to 2, 4962 and probability amounted to 0,012 , where the value is smaller from 0.05 (at a significant level of $5 \%$ ), it can be concluded that there is a significant influence between Organizational Communication ( $X$ 2) on Employee Performance ( $\mathrm{Y}$ ) through Work Motivation (Z). Thus Work Motivation is a variable that becomes an intervening relationship between Organizational Communication and Employee Performance. This result at the same time supports the fourth hypothesis $(\mathrm{H} 4)$ which states " $\mathrm{H} 4$ : Organizational communication intervening with motivation has a positive effect on employee performance at the Youth and Sports Center."

Effect of Discipline at the Youth Center and Sports Yogyakarta. Based on the results of the test using PLS, it proves that work discipline has a significant positive effect on employee performance. Discipline is an attitude about a person's willingness and willingness to obey and obey the prevailing norms around him. Good employee discipline will accelerate in achieving organizational goals, while a decreased or decreased discipline will become a barrier and slow down the achievement of organizational goals.

Effect of Discipline that in mediation by Motivation Work to Employee performance at the Youth Center and Sports Yogyakarta. Descriptive results showed employees give the lowest ratings on indicators of work discipline variable never late and always present on time. Thus there are still some employees who are not present on time, because the assessment is still in the low category. In government agencies, working hours and times to leave work have been regulated in laws or regional government regulations, so it is mandatory for employees to arrive on time. In order for these rules adhered to by all employees of the need to continue in informed and socialized to subordinates to obey the rules and if there will be no warning even strict sanctions.

\section{CONCLUSION}

Based on the analysis and discussion been described, then as for the conclusions that can be obtained from this study are:

- There is a positive and significant influence of work discipline on the performance of the Yogyakarta Youth and Sports Center employees. It shows that higher labor discipline the employee's performance will increase; 
- There is a positive and significant effect of work discipline on the performance of the Yogyakarta Youth and Sports Center employees with work motivation as a mediating variable. This interpreted by the higher her work discipline then work motivation will be higher so that its performance will also participate to increasing.

\section{SUGGESTIONS}

Based on the above conclusions, several suggestions are presented. Suggestions were submitted based on the assessment of employees who are still considered less liking or purpose in the institution. The suggestions are as follows:

- This research, apart from its limitations, can be used as material for consideration of policies in agencies, especially for employees at the Yogyakarta Youth and Sports Center. If necessary, superiors should set an example for employees so that they can be imitated and emulated;

- Lowest Rate organizational communication variables in the indicator's existing employees at the office have high morale. Therefore superiors should continue to provide encouragement and to provide good feedback so that employees work harder, to make policy - policy of the organization let's always communicated with subordinates, provide facilities and opportunities subordinates to give idea or ideas they are useful to the organization.

\section{REFERENCES}

1. Sugiyono, (2012) Educational Research Methods (Quantitative, Qualitative, and R \& D Approaches). Alfabeta. Bandung.

2. Supranto, J. 1997. Customer Satisfaction Level Measurement: To Increase Market Share. Rineka Cipta: Jakarta.

3. Arikunto, S (2006), Research procedures: a practical approach. PT Rineka Cipta.

4. A.A. Anwar Prabu Mangkunegara, 2013, Corporate Human Resource Management, Youth Rosdakarya, Bandung.

5. Azwar, S. (2011) Reliability and Validity (3rd ed) Yogyakarta: Student Library.

6. Ghozali, I. (2011) Multivariate Analysis Application with SPSS Program, Semarang: Diponegoro University.

7. Martoyo, Susilo. 2002. Human Resource Management. BPFE. Yogyakarta.

8. Hasibuan, Malayu SP, 2015. Human Resource Management, STIE YKPN, Yogyakarta.

9. Handoko, Hany. 2001. Human Resource Management. Yogyakarta: BPE.

10. Hartatik, Indah Puji. 2014. Developing Human Resources, Publisher Laksana.

11. Purnomowati, 2006, The Influence of Ability, Motivation and Career Development on Employee Performance of the editorial staff of PT Riau Pos Intermedia Pekanbaru.

12. Pace, R. Wayne and Faules, Don F, 2013, Organizational Communication Strategies to Improve Company Performance, Translation from: Dedy Mulyana, Eighth Printing, Bandung; Rosdakarya youth.

13. Rivai. 2006. Human Resource Management for Companies, Rajagrafindo Persada.

14. Bilson Simamora. 2005. Multivariate Analysis of Marketing. Gramedia Pustaka Utama.

15. Umar, Husein. 2003. Business an Introduction. Jakarta: PT Gramedia Pustaka Utama.

16. Morissan (2013), Communication theory: Individual to Mass. Jakarta: Kencana Prenada Media Group.

17. Marwansyah, 2010. Human Resource Management, Bandung: Alfabeta.

18. Arni, Muhammad. 2009. Organizational Communication. Jakarta: Earth Literacy.

19. Suprapto, Tommy, 2011. Introduction to Communication Science and the Role of Management in Communication, Jakarta: PT. Exciting Book.

20. Udayanto, Rahmat Restu, 2015. The Influence of Internal Communication and Work Discipline on Employee Performance at PT Coca-Cola. e-Journal bisma Ganesha Education University Department of Management (volume 3 of 2015).

21. Bungin, Burhan. 2006. Sociology of Communication. Jakarta: Prenada Media Group. 
22. Wake up, W. (2012). Human Resource Management. Jakarta: Erlangga.

23. Komala, Lukiati, (2009). Perspective, Process, and Context Communication Studies, Bandung: Widya Padjajaran.

24. Effendy, Onong Uchjana (2007), Communication Science (Theory and Practice), Bandung: PT. Rosdakarya youth.

25. Maharani, Intan Ratna, 2010. The Influence of Work Discipline Application on Employee Work Performance of Ciamis Regency Education Office. Journal of Management and Organization Vol I, No. 3, December 2010.

26. Masyjui, Isnan. 2005. The Effect of Motivation and Work Discipline on Job Satisfaction of Employees of the National Education Service Office, Semarang State University.

27. Putri, Merysha Cahyanti Dwi, 2016. Organizational Communication and Organizational Commitment Influence Job Satisfaction in Pusair Bandung Companies. Thesis Management Study Program, Faculty of Economics, Indonesian Computer University.

28. Supriyanto, Sapto, Hamzah, Djabir, Kadir, Abdul Rahman. 2013. The influence of individual characteristics and organizational characteristics on work motivation and performance of employees of the engineering technical development \& support department of PT. Vale Indonesia Tbk. Journal of Magister Management of Hasanuddin University, Makassar, 1 - 12.

29. Istiqomah, Siti Noer, 2015. The Influence of Work Discipline and Communication Climate on Employee Performance of Yogyakarta City Transportation Agency, with work motivation as an intervening variable. Postgraduate Program, Faculty of Economics, Islamic University of Indonesia.

30. Rogers, Eveerett M, and F Floid Shoemaker, Communication of Innovations, Second edition, The Free Press, Collier-macMillan, New York-London, 1971.

31. Afianto, Izaz Dany. 2017, The Effect of Work Discipline and Organizational Communication on Job Satisfaction and Employee Performance (Study on Employees of the Marketing Division of PT. Victory International Futures Malang City)

32. Robbins, Stephen $P$, and Judge, Timoty A. 2008. Organizational Behavior, Translation: Diana Angelica, Ria Cahyani and Abdul Rosyid, Book 2, Edition 12. Salemba Empat.

33. Fuad Mas'ud (2004). Organizational Diagnostic Survey. Concept and Application. UNDIP Publishing Agency, Semarang.

34. Supriadi, E, 2015. Relationship between Instructional Leadership of Headmaster and Work Discipline and Work Motivation and Academic Achievement in Primary School at Special Areas of Central Jakarta. Journal of Education and Learning, Vol. 4 (3): 123-135.

35. Sukanto Reksohadiprojo and T. Handoko, 2001, Personnel Management, BPFE-UGM.

36. Siagian P, Sondang. (2002). Tips for Increasing Work Productivity. Jakarta Rineka Cipta.

37. Siagian P, Sondang. (2012). Motivation Theory and Its Application. Jakarta Rineka Cipta.

38. Sutrisno, E, 2011. Human Resource Management. Golden Prenada Media Group.

39. Saripuddin, Jasman (2017). Effect of Discipline and Motivation on Employee Performance (study at PT. Kemasindo Cepat Nusantara Medan).

40. Mulyasa. (2009). Madrasah Based Management, Concept, Strategy and Implementation. Jakarta: Youth Rosdakarya.

41. Mohamad Zamzam Mokodompit, et al. 2016. Influence Of Leadership Style, Work Motivation and Discipline On Employees Performane CV Sumber Rejeki, International Business Administration, Faculty of Economics and Business Sam Ratulangi University, Manado 95115, Indonesia.

42. Haris Dwi Rukmana, et.al, 2018. The Impact of Organization Communication on Employee Performance Through Employee's Work Motivation at Pt. Putri Panda Unit II Tulungagung, East Java, Indonesia, 1st IRCEB The First International Research Conference on Economics and Business Volume 2018, Faculty of Economics, State University of Malang Jl. Semarang No. 5 Malang, East Java.

43. Tumilaar, Brigita Ria. 2015. The Effect Of Discipline, Leadership, and motivation On Employee Performance at BPJS Ketenagakerjaan, North Sulawesi, Journal of EMBA Vol. 3. Faculty of Economics and Business International Business Administration (IBA) University of Sam Ratulangi Manado Program. 